\title{
Sedimentology and palaeoenvironmental reconstruction of the Early Cambrian Kussak Formation, Salt Range, Pakistan
}

\author{
Shahid Ghazi ${ }^{1}$, Shakeel Ahmad ${ }^{1}$, Muhammad Riaz ${ }^{2,3, *}$ and Tehseen Zafar ${ }^{1,4, *}$ \\ ${ }^{1}$ Institute of Geology, University of the Punjab, Lahore 54590, Pakistan \\ ${ }^{2}$ Department of Earth Sciences, Abbottabad University of Science and Technology, Havelian 22500, Pakistan \\ ${ }^{3}$ Centre of Geographical Information System, University of the Punjab, Lahore 54590, Pakistan \\ ${ }^{4}$ Institute of Geochemistry, Chinese Academy of Sciences, Guiyang 550081, China
}

\begin{abstract}
Comprehensive sedimentological and sequence stratigraphic analyses of the Kussak Formation were carried out at the Nilawahan Gorge, the Karuli Section and the Khewra Gorge, Pakistan. The studied Kussak Formation has been grouped into: (1) bioturbated mudstone, (2) interbedded sandstone/shale, (3) sandy dolomite, (4) glauconitic sandstone and (5) laminated sandstone and siltstone. Hard to friable sandstone is present with condensed neobolus beds in the mud at the top. Bioturbation and glauconite are in middle parts, while a few beds of sandy dolomite are also present in the upper and middle parts of the Kussak Formation. These five depositional sequences had developed during the phase of transgression. Mineralogically, the average modal composition classifies it as quartz arenite. Rock fragments belong to the igneous origin, and feldspar grains most likely indicate an igneous and metamorphic source. The field and petrographic study indicate that the source area belongs to arid and semi-arid environments. Presence of wavy and flaser bedding indicates tidal flat deposition. Burrows, mud cracks, and synaeresis cracks indicate supra-tidal environment. Subsurface data show the finning upward sequence that confirms the deposition during transgression. In summary, the environment of deposition is subtidal, intertidal to supra-tidal environment. Palaeogeographic setting shows that the Kussak Formation source belongs to Aravalli and Malani ranges.
\end{abstract}

Keywords: Depositional environment, lithofacies, provenance, sedimentology, sequence stratigraphy.

THE Cambrian strata are present throughout the Salt Range and the Khisor Range of Pakistan, with best exposures in the eastern part, comprising the Khewra Sandstone, Kussak Formation, Jutana Formation and Baghanwala Formation ${ }^{1-3}$. Wynne . $^{4}$ proposed the name 'obolus beds' or 'siphonotrata beds' to the predominant Kussak Formation. Waagen ${ }^{5}$ used the name 'Neobolus

*For correspondence. (e-mail: riazjass@yahoo.com;

tehseenabbas11@yahoo.com) beds' for the same unit. Noetling ${ }^{1}$ proposed the name 'Kussak Group' while the Stratigraphic Committee of Pakistan formalized the name as Kussak Formation ${ }^{6}$. Further, a thin but widespread conglomerate bed followed by grey silty and sandy glauconitic shale, minor sandstone and a few black shale horizons were described by Bhargava $^{7}$. The strata in the Salt Range are from Eo-Cambrian to late Miocene age ${ }^{8}$. Proterozoic sedimentation abruptly came to an end towards the close of the Early Cambrian $^{9,10}$. The Salt Range of Pakistan comprises of first rocks of the Indian subcontinent recognized to be Cambrian $^{4}$. It is considered the type locality for several taxa with important roles in global Cambrian biostratigraphy and biogeography ${ }^{11}$. Therefore, several researchers emphasize on the biostratigraphy of the Kussak Formation such as trilobites ${ }^{12}$, brachiopods ${ }^{13}$, hyoliths ${ }^{14}$ and mollusks ${ }^{11}$. However, there is a lack of studies on the depositional environment of the Formation. Thus, the present study focuses on the depositional environment of the Kussak Formation through various sedimentological and sequence stratigraphic parameters.

The depositional style of the Kussak Formation is possibly associated with strong tectonic movement(s) related to a major tectonic upheaval affecting the entire Indian subcontinent ${ }^{15}$. Palaeozoic sedimentation initiated in the arm of the Tethyan Ocean along the northern borders of the Indian Plate. The Salt Range area was present at marginal marine environment of the Tethys Sea ${ }^{16}$. The Cambrian sequence in the Salt Range is divided into the Khewra Sandstone, the Kussak Formation, the Jutana Formation and the Baghanwala Formation. The studied Kussak Formation is rich in glauconite, which is evidence for a marine environment. The organic-rich Kussak Formation shows reducing and humid environment, whereas Khewra represents open oxygenating environment with arid climate. This change in environment also shows transgression during the deposition of the Kussak Formation and regression during the deposition of the Khewra Formation.

The studied Kussak Formation in the Nilawahan Gorge, the Karuli Road Section and the Khewra Gorge of the Salt Range comprise of shale, greenish-grey glauconitic 
RESEARCH ARTICLES

Table 1. Generalized lithofacies of the Cambrian strata (Jhelum Group) in the Salt Range, Pakistan ${ }^{3,6,8,10,21-23}$

\begin{tabular}{lccl}
\hline Age & Group & Formation & Lithology \\
\hline Cambrian & Jhelum Group & $\begin{array}{c}\text { Baghanwala Formation } \\
\text { (salt pseudomorph beds) } \\
\text { Jutana Formation } \\
\text { (magnesian sandstone) } \\
\text { Kussak Formation } \\
\text { (magnesian sandstone) } \\
\text { Khewra Sandstone } \\
\text { (purple sandstone) }\end{array}$ & Blood-red shales and flaggy sandstone; with salt pseudomorphs \\
& Grey and purplish shales and glauconitic sandstone; pebble-bed at base & Massive maroon, fine-textured sandstone; maroon shales and flags below \\
\hline
\end{tabular}

micaceous sandstone, interbedded light grey dolomite along with numerous sedimentary structures such as wavy bedding, flaser bedding and hummocky crossbedding. The Kussak Formation in these sections make erosional lower contact with widespread thin layer of conglomerate at the top of the Khewra Sandstone. The upper contact of the formation in the Khewra Gorge and the Karuli Road Section is conformable with the Cambrian Jutana Formation, whereas in the Nilawahan Gorge, it reveals unconformable contact relationship with the Permian Tobra Formation.

\section{Geologic setting}

The Salt Range is the southernmost edge of the Himalayan foreland fold-and-thrust belt ${ }^{16}$. It is the result of collision of the Indian Plate with the Eurasian Plate since the Paleocene $\mathrm{e}^{17,18}$. The Salt Range rises up to $1500 \mathrm{~m}$ from the Punjab alluvial plain and is limited, to the north, by the Potwar and Kohat plateau which separate it from the main Himalayan ranges and to the south by the undeformed foreland of the Jhelum plain ${ }^{17}$. The Salt Range is bounded to the north and south by the Main Boundary Thrust (MBT) and the Salt Range Thrust (SRT) respectively $^{19}$. The Jhelum Fault is the eastern while the Kalabagh Fault is the western boundary of the Salt Range ${ }^{19}$ (Figure 1).

The Salt Range is reflected as the active frontal thrust zone of the Himalaya in Pakistan. One kilometre offset of the basement acted as a decollement that caused the central Salt Range-Potwar Plateau thrust sheet to ramp to the surface, and ultimately exposed the Paleozoic and Mesozoic strata. The frontal part of the thrust sheet was folded passively as it overrode the sub-thrust surface on a ductile layer of the Neoproterozoic salt ${ }^{17}$. The thrust sheet began to override the basement offset from 2.1 to $1.6 \mathrm{Ma}$. The rate of Himalayan convergence that can be attributed to underthrusting of the Indian basement beneath the sediments in the Pakistan foreland is therefore at least 9-14 mm/yr (ref. 20).

Stratigraphy of the Salt Range extends from the Neoproterozoic to Late Miocene ${ }^{6,8,10}$. Abrupt transition of sedimentation occurred from the Proterozoic to Early Cambrian, possibly due to tectonic movements that affect the entire Indian subcontinent ${ }^{15}$. The Cambrian strata in the Salt Range are divided into four rock units of formation, namely Khewra Sandstone, Kussak Formation, Jutana Formation and Baghanwala Formation (Table 1). They combine to form the Jhelum Group $3,6,8,10,21-23$. These sediments are deposited in shallow marine environment with fluctuating sea-level changes.

\section{Materials and methods}

The Early Cambrian Kussak Formation was comprehensively studied in the Nilawahan Gorge $\left(72^{\circ} 35^{\prime \prime} 16^{\prime} \mathrm{E}\right.$, $\left.32^{\circ} 38^{\prime \prime} 16^{\prime} \mathrm{N}\right)$, the Karuli Road Section $\left(72^{\circ} 46^{\prime \prime} 33.76^{\prime} \mathrm{E}\right.$, $\left.32^{\circ} 43^{\prime \prime} 04.50^{\prime} \mathrm{N}\right)$ and the Khewra Gorge $\left(73^{\circ} 00^{\prime \prime} 14^{\prime} \mathrm{E}\right.$, $\left.32^{\circ} 40^{\prime \prime} 12^{\prime} \mathrm{N}\right)$ of the Salt Range where its thickness is 55 , 60 and $75 \mathrm{~m}$ respectively (Figure 1). Detailed field study, with an aim to reconstruct the depositional environment of the Kussak Formation exposed in the Khewra Gorge and the Nilawahan Gorge sections was taken up. Based on field observations, a detailed lithological log of the Kussak Formation was prepared (Figure 2). For a comprehensive study, samples of the Kussak Formation were collected from two sections, including the Khewra Gorge and the Nilawahan Gorge of the Salt Range. Twenty-two slides were prepared for thin-section study. Textural, mineralogical, depositional as well as provenance studies of systematically obtained sandstone samples were done under polarizing microscope to estimate the main constituents for their classification. Various models of sandstone classification were used to determine the detrital grains. In the present study, we used Pettijohn ${ }^{24}$ and Folk ${ }^{25}$ models of sandstone classification that provide the percentage of three framework grains, i.e. quartz, feldspar and rock fragment, on a QFL ternary diagram.

Furthermore, well log-based analysis was carried out for the interpretation of depositional environment of the formation by Pakistan Oilfields Limited (POL) in 1988. For this, petrophysical studies of Turkwal Deep 1 $\left(72^{\circ} 59^{\prime} 18.23^{\prime \prime} \mathrm{E}, 33^{\circ} 07^{\prime} 01.46^{\prime \prime} \mathrm{N}\right)$ were carried out that was drilled at $4321 \mathrm{~m}$ in Rawalpindi district, about $5000 \mathrm{~m}$ north of Dudial town, Pakistan. The average ground elevations of the Turkwal well is $514 \mathrm{~m}$ and with the Kelly Bushing is $522 \mathrm{~m}$ respectively. 
RESEARCH ARTICLES

\section{Kussak Formation}

\section{Lithofacies analysis}

The macroscopic features of the Kussak Formation were comprehensively studied at the Nilawahan Gorge, the Karuli Road Section and the Khewra Gorge where it is associated with five lithofacies, which are described below.

Bioturbated mudstone (Ksb): This lithofacies forms the lower part of the formation in the studied sections (Figure 2 ). The facies is mainly associated with mudstone and intercalations of fine-grained sandstone and siltstone that make the condensed section of the formation (Figure $3 a$ ). Moreover, bioturbation was observed in fine-grained sandstone (Figure $4 a$ ). Some black shale intercalations were also present, which indicate horizontal lamination and splintery nature. This light grey to rusty brown lithofacies consists of mica in relatively large amount (Figure $3 a$ ). The intensity of bioturbation is variable in the

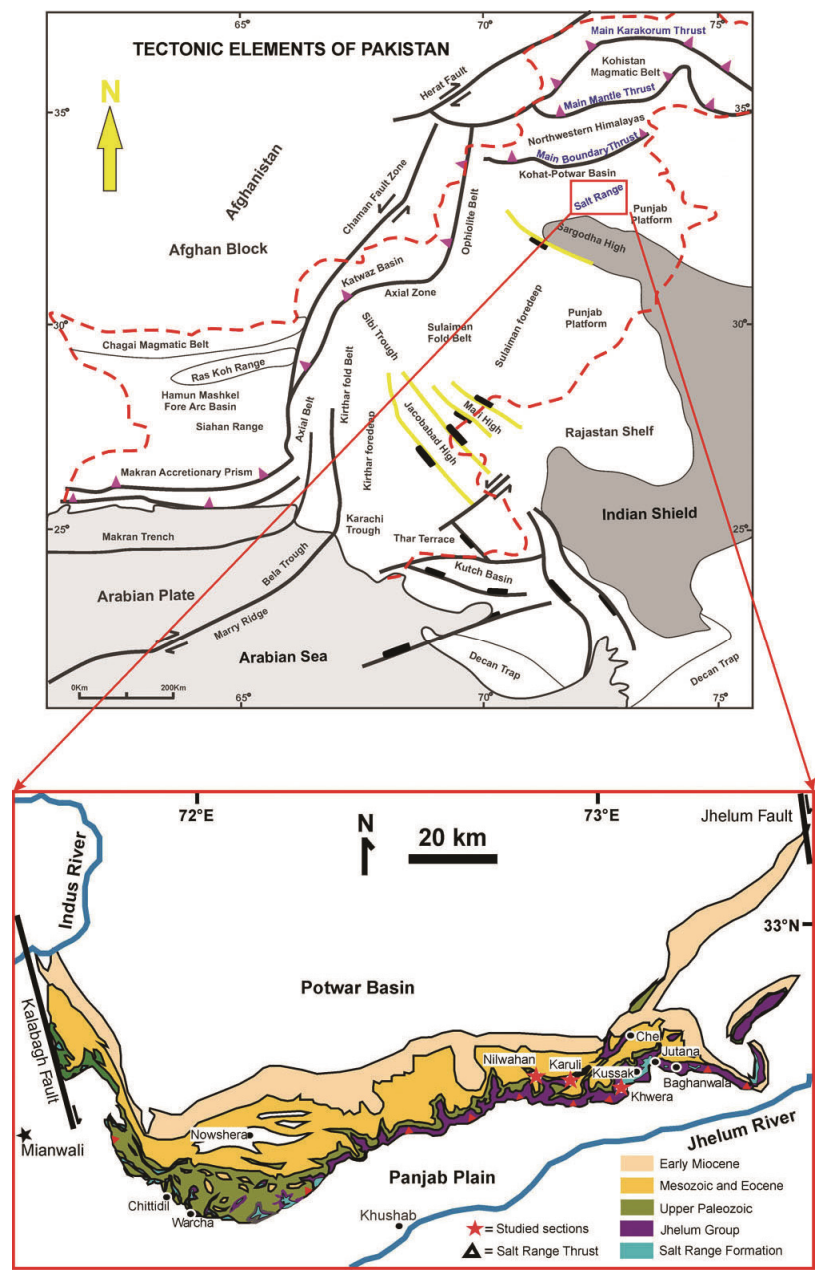

Figure 1. Geological map and location of the Nilawahan Gorge, the Karuli Road Section, and the Khewra Gorge in the Salt Range, Pakistan. Locations are shown with red star (modified after Hughes et al. ${ }^{3}$ ).

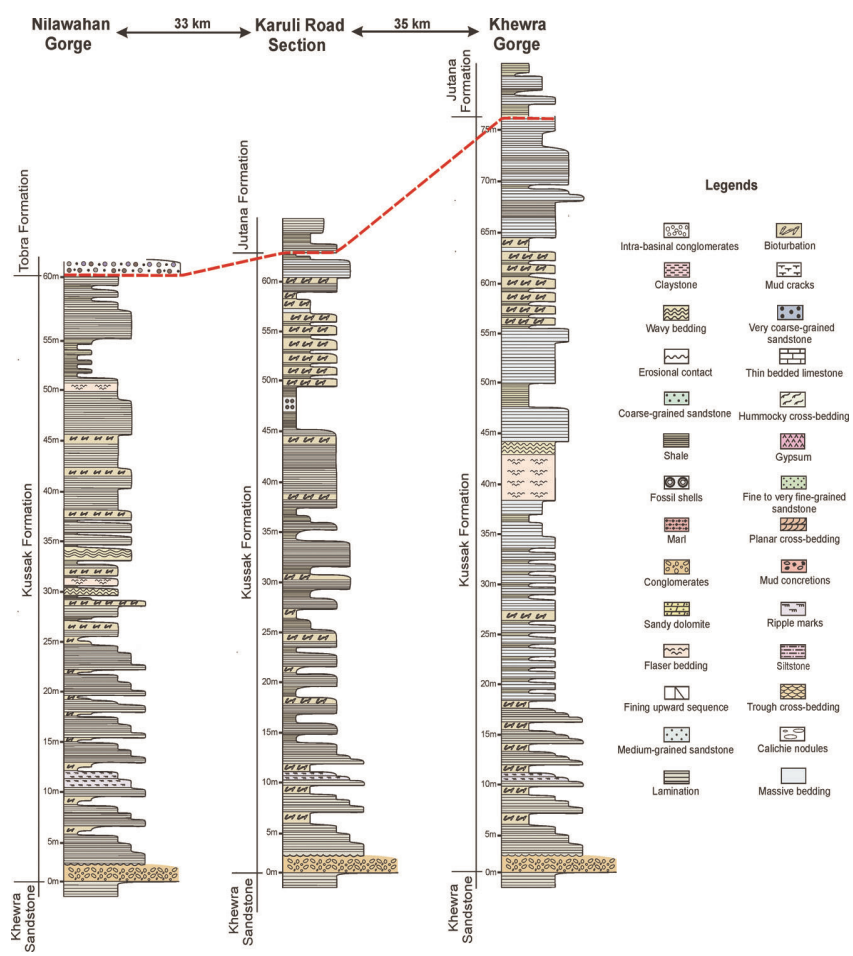

Figure 2. Stratigraphic columns of the Cambrian Kussak Formation in the Nialawahan Gorge, the Karuli Road Section and the Khewra Gorge showing the ordering of small- and medium-scale cycles in fining upward cycles.

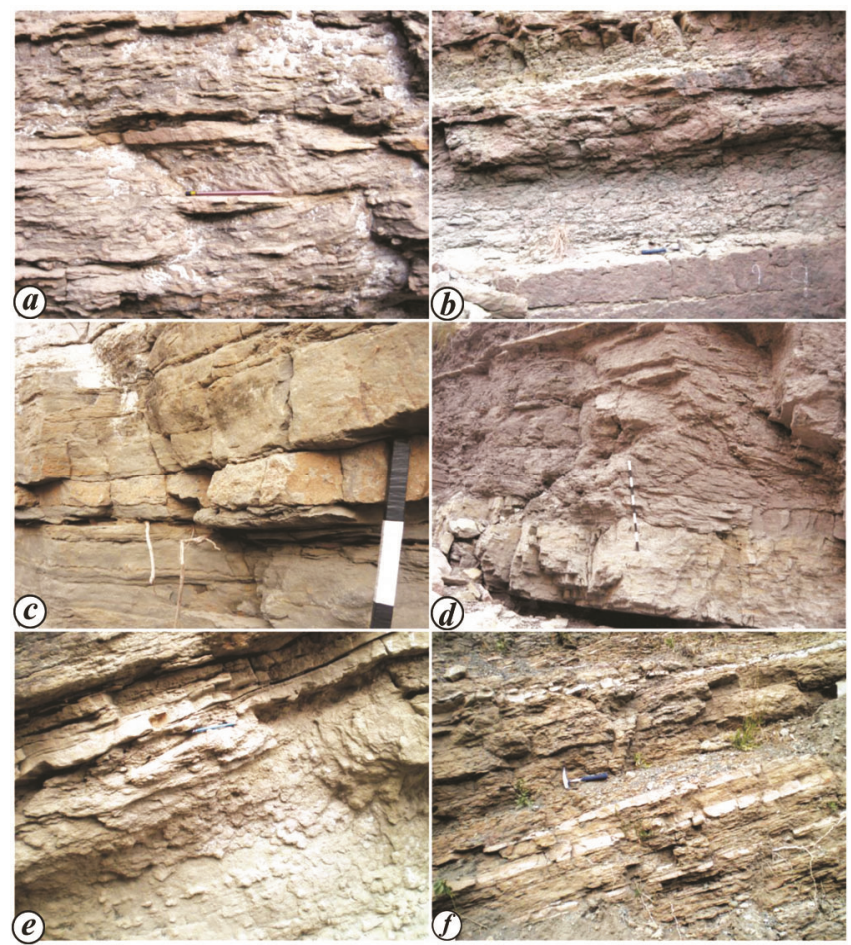

Figure 3. Association of lithofacies in the Cambrian Kussak Formation in the study region. $\boldsymbol{a}$, Bioturbated mudstone; $\boldsymbol{b}$, interbedded sandstone and shale; $\boldsymbol{c}$, sandy dolomite; $\boldsymbol{d}, \boldsymbol{e}$, glauconitic sandstone; $f$, laminated sandstone/siltstone (hammer and pencil are for scale). 


\section{RESEARCH ARTICLES}

Kussak Formation (Figure $4 a$ ). Some beds are intensely bioturbated and their original fabric is destroyed, while others show relatively minor bioturbation and the original fabric of the rock is preserved.

Bioturbated mudstone and presence of condensed section indicate that this facies is deposited in shelf environments with starved sedimentation condition. The condensed section represents maximum shoreline transgression.

Interbedded sandstone/shale (Ksh): The lithofacies consists of fine-grained, well-sorted sandstone, siltstone and shale that are interbedded (Figures 2 and $3 \mathrm{~b}$ ). The lithofacies has higher proportion of shale and siltstone compared to sandstone (Figure $3 \mathrm{~b}$ ). Shale is greenish-grey or pale yellow-green. In addition, the lithofacies also contains flasers (Figure $4 b$ ), and wavy beds in ripple crossstratified sandstone (Figure $4 c-e$ ).

The interbedded sandstone/shale lithofacies is mud or mixed sand/mud tidal flat. These include thinly interlayered bedding, coarsely interlayered bedding, flasers, wavy bedding and clay drapes. The mixture of clay and sand is characteristic of mud tidal flat facies. Flaser bedding appears to form under fluctuating depositional conditions marked by periods of current activity, when traction transport and rippling of fine sands take place,

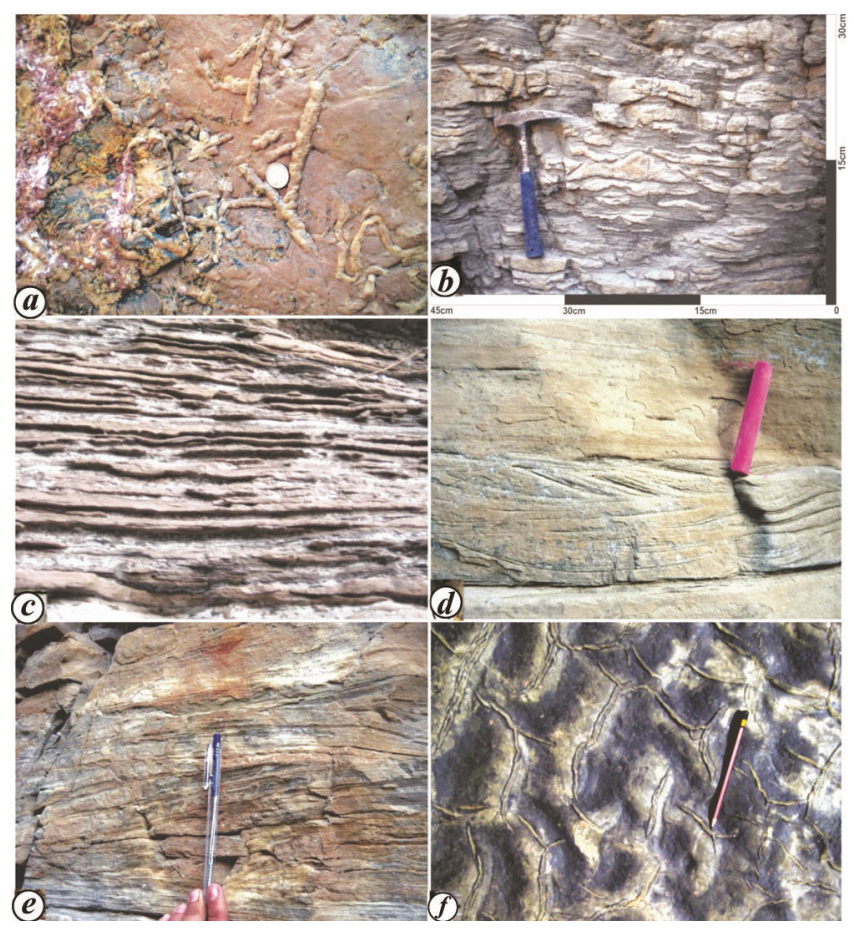

Figure 4. Sedimentary structures in studied sections of the Cambrian Kussak Formation. a, Bioturbation observed in bioturbated mudstone $\boldsymbol{b}$, flaser bedding; $\boldsymbol{c}$, wavy bedding; $\boldsymbol{d}$, hummocky cross-bedding; $\boldsymbol{e}$, ripple cross-lamination. $\boldsymbol{b}-\boldsymbol{e}$, Structures examined in 'interbedded sandstone/shale' lithofacies of the Kussak Formation; $\boldsymbol{f}$, Synaeresis cracks observed in 'laminated sandstone and siltstone' lithofacies of the Kussak Formation (hammer and pencil are for scale). alternating with periods of quiescence, when mud is deposited (Figure $4 b$ ). Repeated episodes of current activity result in flaser bedding which is a type of ripple bedding in which thin streaks of mud occur between sets or cross-laminations (Figure $4 b$ ). Flaser bedding suggests deposition under fluctuating hydraulic conditions.

Sandy dolomite $(K s d)$ : The studied facies is characterized by thin to medium-bedded, planar-laminated, dolomite with intercalations of mudstone (Figures 2 and $3 \mathrm{c}$ ). Sandstone gives a greenish tint due to the presence of glauconite (Figure $3 c$ ).

Presence of glauconite mineral is an indicator of shallow marine environment of deposition.

Glauconitic sandstone (Kgs): This lithofacies is associated with siltstone to very fine-grained glauconitic sandstone (Figures 2 and $3 d$ ). The glauconitic sandstone ranges in size from silt to very fine, well-sorted sand (Figure $3 e$ ). Moreover, this lithofacies has variable composition compared to other lithofacies, ranging from highly feldspathic arenite to highly glauconitic arenite.

Based on the ubiquity of glauconite and on its sedimentary structures, the green-sand lithofacies is interpreted as shallow marine sandstone.

Laminated sandstone and siltstone $(K s l)$ : The observed lithofacies comprises of thin to medium-bedded, planar laminated, well-sorted, very fine to medium-grained sandstone (Figures 2 and $3 f$ ). Very thin to thin-bedded siltstone along with local synaeresis cracks are also observed (Figures $3 f$ and $4 f$ ). Moreover, siltstone and sandstone are interlayered that contain ripple crossstratification and fine planar stratification.

The shale/siltstone lithofacies is interpreted as lagoonal sediment with smaller amounts of tidal flat sediment. Lagoonal sediment consists of quiet-water shale deposits. The lithofacies also includes interbedded and interfingering sandstone, and siltstone and shale lithologies; these represent a number of overlapping sub-environments.

\section{Sandstone petrography of the Kussak Formation}

Petrographic studies of the Kussak Formation were performed, which comprised of grey silty and sandy glauconitic shale with intercalations of some sandstone and a few black shales. Thin sections were prepared in order to determine the detrital components of sandstone. The detailed petrographic descriptions of sandstone components in two sections are given below.

\section{Petrographic features of the Kussak Formation in the Khewra Gorge}

Thin sections of five sandstone samples of the Kussak Formation were prepared to understand the major detrital 
components of sandstone. Detailed descriptions of these samples are given below.

Microfacies S-04: Based on textural characteristics, sandstone is medium-grained. Detrital composition is dominated by $90 \%$ quartz content. Other components are feldspars $4-5 \%$, few lithic fragments, accessory minerals such as hematite and mica about $2 \%$. Matrix is about 2 $3 \%$ of the bulk composition (Figure 5).

Quartz grains are mostly monocrystalline and rarely polycrystalline. They are generally medium-grained, subangular to sub-rounded, and moderately sorted showing mainly sutured and concavo-convex contacts. These grains show undulatory extinction when examined under cross-polarized light. Feldspar grains are mainly orthoclase, microcline and plagioclase. The matrix appears to be composed of clays minerals. The major cement in sandstone is hematite. Minor amounts of calcite and silica are also present that act as cement.

Microfacies S-09: Sandstone is moderately to wellsorted, fine- to medium-grained. Detrital composition is dominated by quartz content of $85 \%$. Other components are feldspar 5\%, rare lithic fragments, accessory minerals such as hematite and mica about $2 \%$. Matrix is about 5 $7 \%$ of the bulk composition (Figure 5).

Quartz grains are mostly monocrystalline and rarely polycrystalline. They are generally medium-grained, sub-

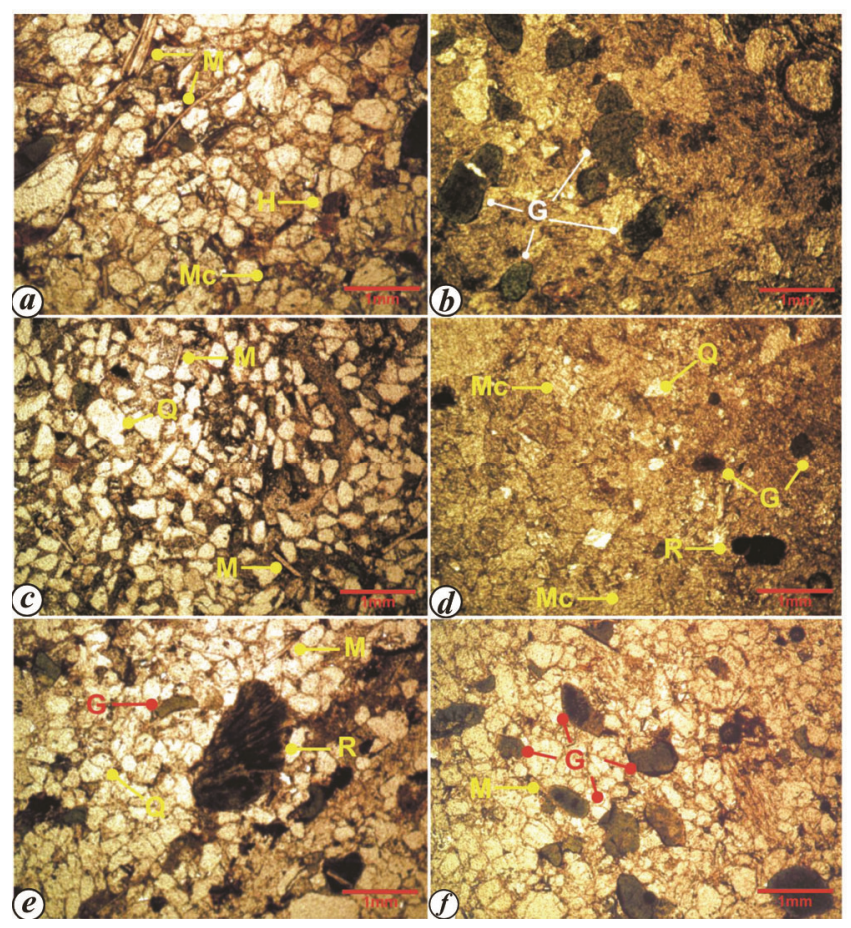

Figure 5. Representative characteristics of microfacies of the Cambrian Kussak Formation in the Khewra Gorge, and the Nilawahan Gorge. $\boldsymbol{a}-\boldsymbol{f}$, Plane-polarized views. Q, Quartz; R, Lithic fragment; $\mathrm{G}$, Glauconite; Mc, Microcline; H, Hematite (all in same scale). angular to sub-rounded, showing mainly sutured and point contacts. Feldspar grains are mainly orthoclase, microcline and plagioclase. The matrix appears to be composed of clay minerals. Veins are generally filled with clay minerals and some are filled with calcite. The major cementing material in sandstone is hematite.

Microfacies $S-15$ : Sandstone is medium- to coarsegrained, sub-angular to sub-rounded and moderately sorted. It is composed of about $85 \%$ quartz and $2 \%$ feldspar. Lithic fragments are about $2 \%$, mica and other accessory minerals are about $2 \%$. Sandstone contains $3 \%$ glauconite and 7\% clay matrix (Figure 5).

Quartz grains are monocrystalline and few are fractured. The quartz grains have sutured and concavoconvex contacts. The dominant type of cement is silica. Ferruginous cement such as hematite is also present at some places.

Microfacies $S$-18: Sandstone is fine- to medium-grained. Detrital composition is dominated by quartz content of $85 \%$. Other components are feldspar $3 \%$, lithic fragment are very rare, and accessory minerals such as hematite and mica are about $2 \%$. Matrix is about $5 \%$ of the bulk composition. Also, 5\% glauconite is present (Figure 5).

Quartz grains are mostly monocrystalline and 5\% are polycrystalline. They are generally medium-grained, subangular to sub-rounded, depicting mainly concavoconvex and point contacts. Feldspar grains are mainly plagioclase and some are orthoclase. The matrix is composed of clay minerals. The major cement in sandstone is hematite, while minor amounts of calcite and silica are also present.

Microfacies $S-22$ : Sandstone is medium- to coarsegrained and comprises of $80 \%$ quartz, $4-5 \%$ feldspar, $5 \%$ lithic fragment, $2 \%$ hematite and mica, 2-3\% matrix and $2-3 \%$ glauconite (Figure 5 ).

Quartz grains are mostly monocrystalline and approximately $10 \%$ are polycrystalline. Generally, they are medium-grained, sub-angular to sub-rounded. These grains are moderately sorted and display mainly sutured and concavo-convex contacts. Feldspar grains are mainly orthoclase, microcline and plagioclase. The matrix appears to be composed of clays minerals. The major cement in sandstone is hematite. Minor amounts of calcite and silica are also present.

\section{Petrographic features of the Kussak Formation in the Nilawahan Gorge}

Thin sections of four sandstone samples of the Kussak Formation in the Nilawahan Gorge were also prepared to determine the detrital components. 
Microfacies S-17: Sandstone is medium-grained and quartz $(93 \%)$ is the major detrital component of the microfacies. Besides quartz, feldspar components such as orthoclase, microcline and plagioclase are $2 \%$, few lithic fragments, accessory minerals (i.e. hematite and mica) are about $2 \%$ and clay minerals $(2-3 \%)$ are also present.

Quartz grains are mostly monocrystalline and rarely polycrystalline, and generally medium grained, subangular to sub-rounded showing sutured and concavoconvex contacts. The major cement in sandstone is hematite and minor amounts of calcite and silica are also present.

Microfacies S-18: Sandstone is medium-grained and dominated by $88 \%$ quartz. Orthoclase, microcline and plagioclase are about $5 \%$, lithic fragments are rare, hematite and mica are about $2 \%$, and matrix is about $5-7 \%$ (Figure 5).

Mostly monocrystalline grains along with few polycrystalline grains are sub-angular to sub-rounded, representing mainly sutured and point contacts and showing undulatory extinction under cross-polarized light. Veins are filled with clay minerals and some are filled with calcite. The major cement in sandstone is hematite.

Microfacies S-19: Sandstone is medium- to coarsegrained, sub-angular to sub-rounded and moderately sorted. Sandstone is composed of about $90 \%$ quartz, $2 \%$ feldspar, rarely lithic fragments, $2 \%$ mica and other accessory minerals, 3\% glauconite and 3\% clay matrix (Figure 5).

\begin{tabular}{|c|c|c|c|c|}
\hline Period & Formation & Sequence & Relativ & vel \\
\hline & & & High & Low \\
\hline Permian & Tobra & & & \\
\hline \multirow{11}{*}{ 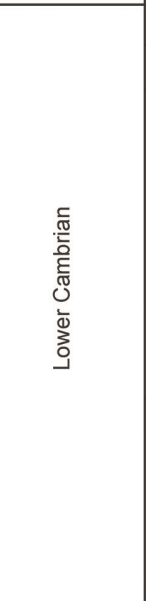 } & Baghanwala & & & \\
\hline & Jutana & & & \\
\hline & \multirow{5}{*}{ Kussak } & KK-5 & & \\
\hline & & KK-4 & & \\
\hline & & KK-3 & & \\
\hline & & KK-2 & & \\
\hline & & KK-1 & & \\
\hline & \multirow{4}{*}{$\begin{array}{l}\text { Khewra } \\
\text { Sandstone }\end{array}$} & KW-4 & & \\
\hline & & KW-3 & & \\
\hline & & $\mathrm{KW}-2$ & & \\
\hline & & $\mathrm{KW}-1$ & & \\
\hline Pre-Cambrian & $\begin{array}{l}\text { Salt Range } \\
\text { Formation }\end{array}$ & & & \\
\hline
\end{tabular}

Figure 6. Relative sea-level curve of the Cambrian strata, i.e. Khewra Sandstone, Kussak Formation, Jutana Formation and Baghanwala Formation in the study area. This curve is analogous to the Cambrian curve of the North Australia basin ${ }^{26}$.
Quartz grains are monocrystalline. The quartz grains have sutured and concavo-convex contacts. The dominant type of cement is silica. Ferruginous cement such as hematite is also present at some places.

Microfacies S-22: Sandstone is medium- to coarsegrained. Detrital composition is dominated by quartz content of $85 \%$. Other components are feldspar 3\%, lithic fragment are rare, and accessory minerals such as hematite and mica are about $2 \%$. Matrix is about $5 \%$ of the bulk composition and 5\% glauconite is present.

Quartz grains are mostly monocrystalline and rarely polycrystalline, and generally sub-angular to sub-rounded showing mainly sutured and point contacts. The major cement in sandstone is hematite, and minor amounts of calcite and silica are also present as cementing material.

\section{Facies association and sequence stratigraphy}

The Cambrian strata in the study area of the Salt Range developed with fluctuating sea-level change that formed a depositional sequence. This complete sequence has five subsequences along with clear sequences boundaries such as maximum flooding surface (MFS), maximum regressive surface (MRS), and sub-areal unconformity (Figure $6)^{26}$. Detailed descriptions of these sequences of the Kussak Formation are given below.

\section{Sequence KK-1: laminated, medium-bedded micaceous}

This is the lowermost sequence of the Kussak Formation. A bed of conglomerate is present at the base of this sequence, which is known as basal conglomerate, followed by very coarse to fine-grained, laminated sandstone intercalated with siltstone and claystone along with bioturbation (Figure $7 a$ and $b$ ). The sequence associated with five fining upward sequences shows cyclicity, as observed in the field (Figure 2). At places, glauconite is occasionally present. Moreover, small-scale cross-laminations are present in the sequence. Lithology is easily recognizable from the facies. There is no remarkable difference in lithology in the Nilawahan Gorge and the Khewra Gorge of the Salt Range (Figure $7 a$ and $b$ ).

\section{Sequence KK-2: medium, cross-bedded, glauconitic}

This greenish-grey sandstone and sandy shale sequence is about $5 \mathrm{~m}$ thick in the Nilawahan Gorge, and $6 \mathrm{~m}$ thick in the Khewra Gorge. It has two fining upward sequences which comprise of fine-grained, laminated sandstone intercalated with siltstone and claystone (Figure 2).

CURRENT SCIENCE, VOL. 119, NO. 10, 25 NOVEMBER 2020 
Sequence KK-3: medium, planner-bedded, dolomitic sandstone

This sequence consists of five small sequences, which are composed of medium- to fine-grained laminated sandstone. Moreover, $1 \mathrm{~m}$ thick bed of siltstone and claystone is observed in the middle part of the sequence (Figure 2).

\section{Sequence KK-4: fine-grained, rippled sandstone}

This sequence is $25 \mathrm{~m}$ thick and composed of fine- to medium-grained sandstone and glauconitic shale. Sedimentary structures like bioturbation are commonly observed. It has five sequences, which are composed of fine-grained, laminated bioturbated sandstone, finegrained sandstone with mud concretions, medium-grained sand with horizontal lamination, intercalated with siltstone and claystone (Figure 2). This is the first sequence where a coarsening upward or shoaling upward sequence has been observed.

\section{Sequence KK-5: massive to fine-grained sandstone}

This is the topmost sequence of the Kussak Formation. It is truncated by the Permo-Cambrian unconformity, which has more pronounced affect in the western and central Salt Range (Figure $7 c$ ). This unconformity has removed the Baghanwala Formation, the Jutana Formation, and part of the Kussak Formation in the central Salt Range. Therefore, this sequence is absent in the western part of the Nilawahan Gorge (Figure $7 c$ ). However, it is present in the Khewra Gorge (Figure $7 d$ ) and the Karuli Road

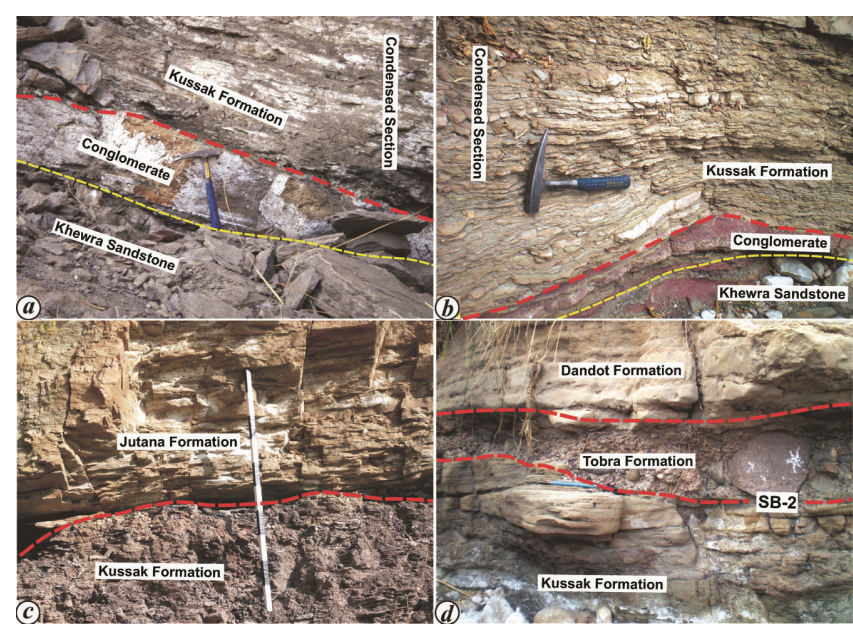

Figure 7. Sequence stratigraphic framework of the Cambrian Kussak Formation in the study area. $\boldsymbol{a}$, Sequence boundary between the Khewra Sandstone and the Kussak Formation. $\boldsymbol{b}$, Sequence boundary between the Kussak Formation marked by conglomerate bed. $\boldsymbol{c}$, Transgressive surfaces between the Kussak and Jutana Formations. d, Sequence boundary II between Kussak, Tobra and Dandot Formations in the Nilawahan Gorge (hammer and pencil are for scale). section. This sequence is composed of fine- to mediumgrained sandstone with symmetrical ripple marks, bioturbation and dolomitic sandstone.

\section{Log-based analysis}

The Turkwal Deep 1 was drilled at a depth of $4321 \mathrm{~m}$ in the southern undeformed zone of the Potwar basin, Pakis$\tan$. The oldest formation encountered in this well is the Neoproterozoic Salt Range Formation (133 m thick) in up-thrown block of the Turkwal thrust. The total thickness of the Kussak Formation measured in this well is $9.5 \mathrm{~m}$. The upper part of the Formation is composed of sandstone, whereas the lower part has mudstone intercalated with sandstone and siltstone. Based on gamma-ray (GR) $\log$ response of the Kussak Formation, four facies were identified which have been correlated with graphic sedimentary log of outcrop in the Khewra Gorge (Figure 8). Detailed descriptions of these facies are given below.

Facies 1 represents $20 \%$ of the total succession of the Kussak Formation, which is characterized by bell-shaped $\log$ motifs in the GR $\log$. The GR value in this facies ranges from 60-72 API, and increases towards the top. The facies has sharp base and represents overall fining upward trends (Figure $8 a$ ).

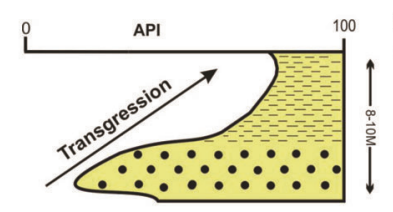

(a) Facies 1

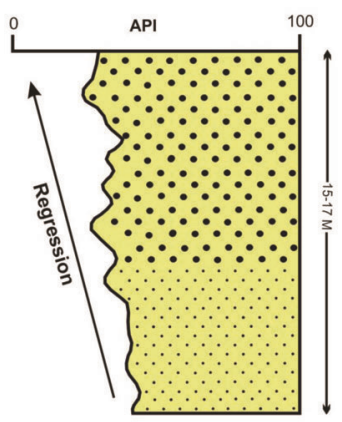

(c) Facies 3

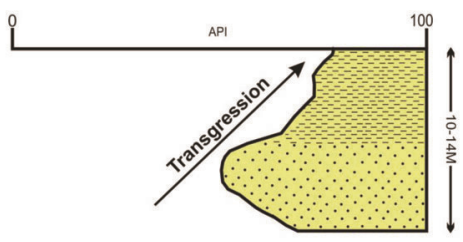

(b) Facies 2

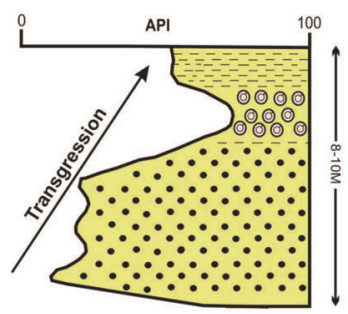

(d) Facies 4
Figure 8. Well logs of the Turkwal Deep 1 (72 $59^{\prime} 18.23^{\prime \prime} \mathrm{E}$, $33^{\circ} 07^{\prime} 01.46^{\prime \prime} \mathrm{N}$ ) depict the subsurface characteristics of the Cambrian Kussak Formation in Potwar Basin, Pakistan. a, Facies 1 represents bell-shaped $\log$ motifs depicting the first subsequence. b, Facies 2 represents bell-shaped $\log$ motifs and forms the second subsequence. $c$, Facies 3 shows funnel-shaped log motifs in which coarsening upward trend is observed, and forms third subsequence. $\boldsymbol{d}$, Facies 4 indicates the bell-shaped log motifs showing finning upward sequence and depicts the fourth subsequence. 
Table 2. Major characteristics of lithofacies of the Cambrian Kussak Formation in the Nilawahan Gorge, the Karuli Road Section and the Khewra Gorge exposed in the Salt Range, Pakistan

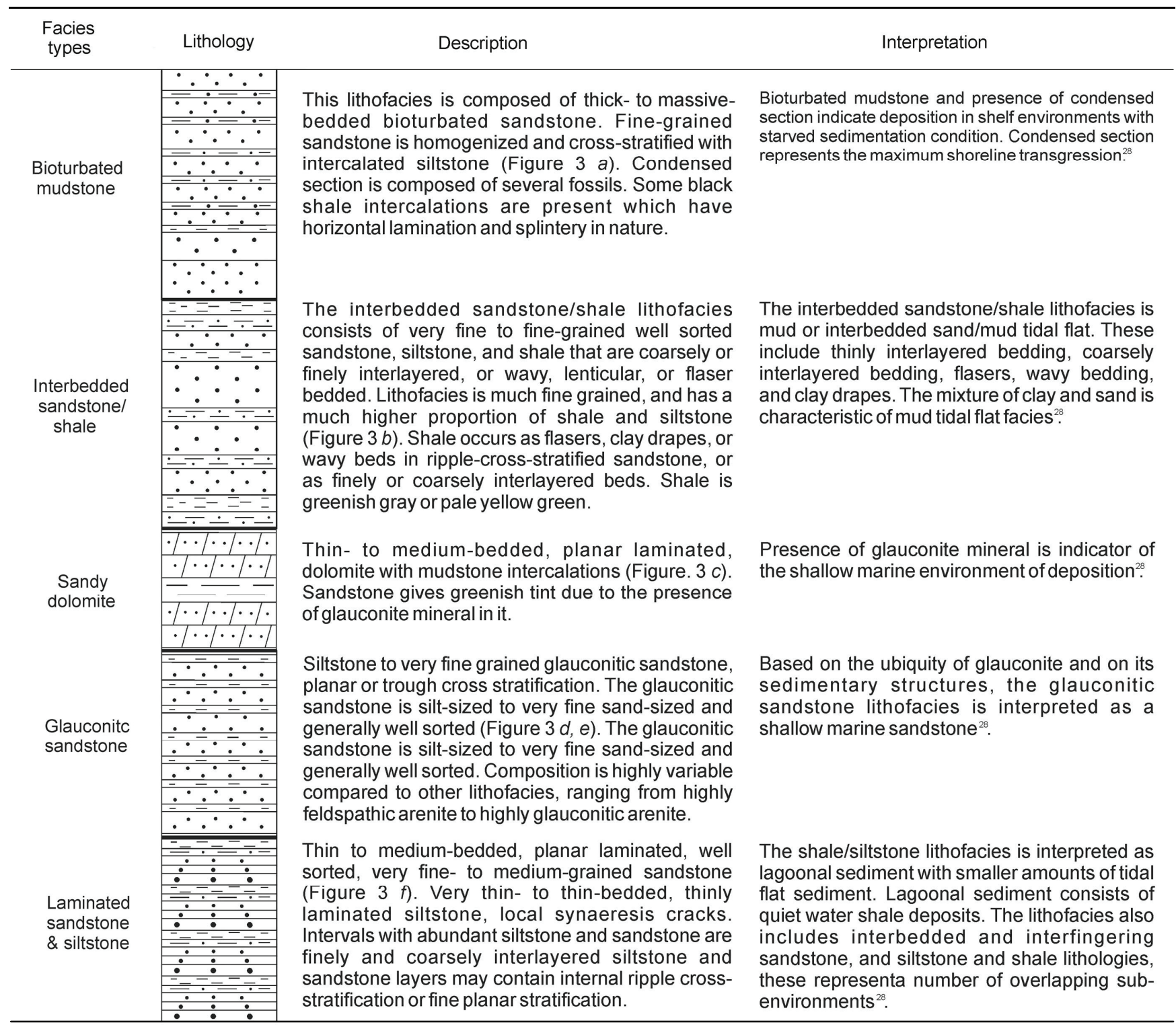

Facies 2 represents $10 \%$ of the total succession and is characterized by bell-shaped log motifs in the GR log. The GR value in this facies varies from 70 to 80 API. Average shale volume increases towards the top (Figure 8 b).

Facies 3 represents $55 \%$ of the total succession of the Kussak Formation. It indicates the characteristics of funnel-shaped motifs in the GR $\log$ (Figure $8 \mathrm{c}$ ). These motifs highlight the coarsening upward sequence, where API values decrease towards the top.

Facies 4 denotes $15 \%$ of the total succession and comprises of the characteristics of bell-shaped motifs in the GR $\log$ (Figure $8 d$ ). The GR value in this facies varies from 60 to 70 API. The overall succession of this facies reveals the fining upward trend (Figure $8 d$ ).

\section{Discussion}

\section{Depositional environment of the Kussak Formation}

Macroscopic interpretation of the Kussak Formation: The Kussak Formation has been comprehensively studied at the Nilawahan Gorge, the Karuli Road Section and the Khewra Gorge exposed in the Salt Range, where its thickness is 55, 60 and $75 \mathrm{~m}$ respectively, representing a typical example of depositional environment of the Formation. The Formation in the study area comprises of bioturbated mudstone, interbedded sandstone/shale, sandy dolomite, glauconitic sandstone, laminated sandstone and siltstone lithofacies (Figure 3 and Table 2) that developed under certain conditions of sedimentation, 
Table 3. Major characteristics of sedimentary structures of the Cambrian Kussak Formation in the Nilawahan Gorge, the Karuli Road Section and the Khewra Gorge exposed in the Salt Range, Pakistan

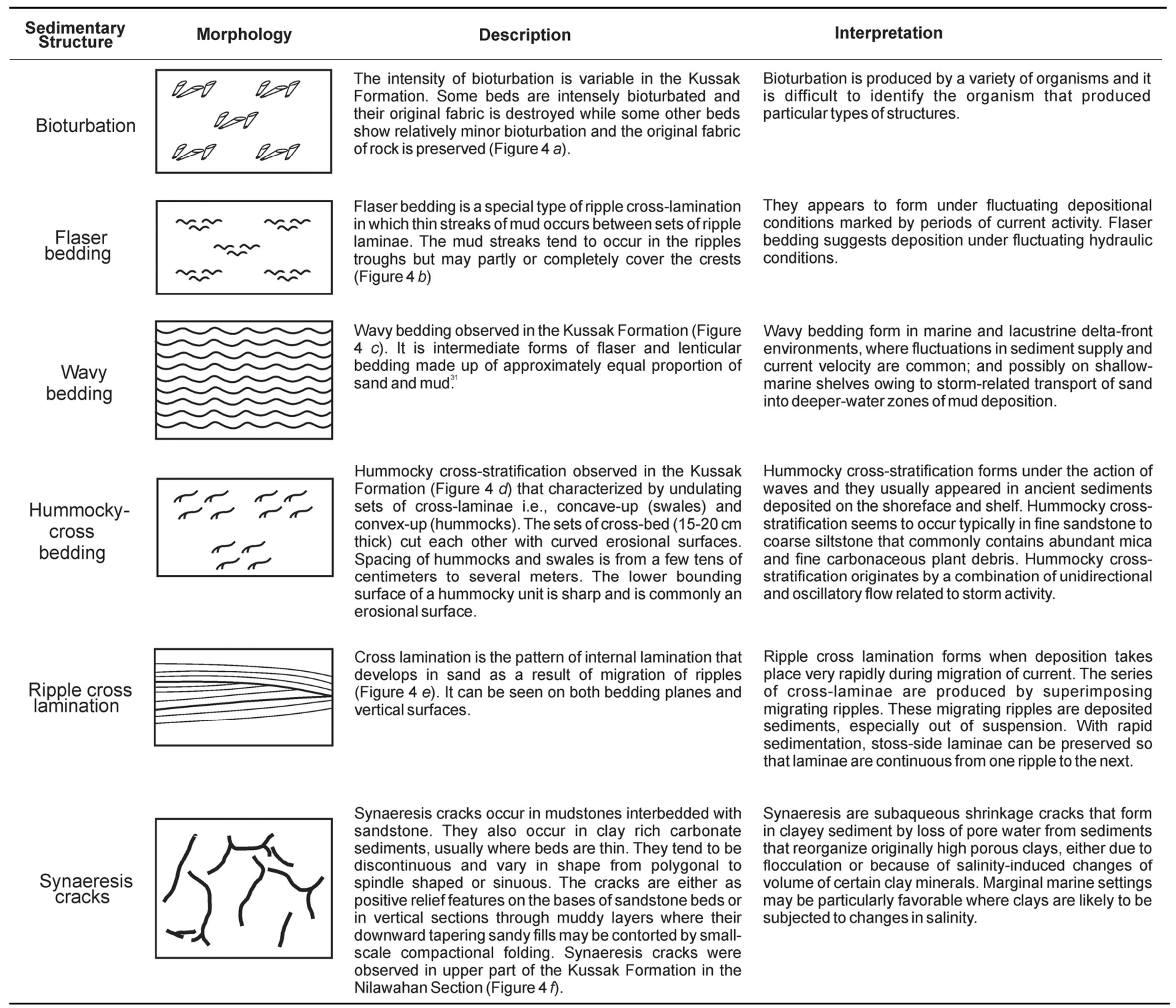

reflecting a particular environment ${ }^{27}$. The bioturbated mudstone and presence of condensed section (Figure $3 \mathrm{a}$ ) indicate that this facies is mainly deposited in shelf environments with starved sedimentation condition ${ }^{28}$. Moreover, condensed section represents the maximum shoreline transgression ${ }^{28}$. The interbedded sandstone/ shale lithofacies is abundantly associated with a mixture of shale, clay and sand (Figure $3 b$ ), indicating the characteristic of tidal flat setting ${ }^{28}$. Moreover, the glauconitic mineral in sandy dolomite (Figure $3 c$ ) and glauconitic sandstone (Figure $3 d$ and $e$ ) depict the shallow marine environment of sandstone ${ }^{28}$. The shale/siltstone lithofacies in laminated sandstone and siltstone (Figure $3 f$ ) is interpreted as lagoonal sediment with small amounts of tidal flat sediment. Lagoonal sediment consists of quietwater shale deposits. The lithofacies also includes inter- bedded and interfingering sandstone, siltstone and shale lithologies that represent a number of overlapping subenvironments in the Early Cambrian Kussak Forma$\operatorname{tion}^{28,29}$.

Furthermore, depositional environment of the Kussak Formation interpreted through sedimentary structures provides invaluable information about the mode and direction of transport and deposition, as well as subsequent changes ${ }^{29,30}$. The typical sedimentary structures of the Kussak Formations such as wavy bedding, flaser bedding, hummocky cross-bedding, synaeresis cracks, bioturbation and ripple cross-lamination are observed in this study area of the Salt Range (Figure 4 and Table 3), which are representative of specific environments of deposition. Bioturbation (Figure $4 a$ ) is produced by a variety of organisms. So, it is difficult to identify the 
organisms that produce a particular type of structure $\mathrm{s}^{31,32}$. Flaser bedding (Figure $4 \mathrm{~b}$ ) appears to form under fluctuating depositional conditions marked by periods of current activity, when traction transport and rippling of fine sand takes place, alternating with periods of quiescence, when mud is deposited ${ }^{32}$. Repeated episodes of current activity result in flaser bedding (ripple bedding) in which thin streaks of mud occur between sets or crosslaminations ${ }^{27,30}$. Flaser bedding suggests deposition under fluctuating hydraulic conditions ${ }^{27,30,33}$. The wavy bedding (Figure $4 c$ ) appears to form in environments that favour deposition of approximately equal proportions of sand and mud, whereas flaser bedding forms under conditions that favour deposition of sand over mud ${ }^{34}$. These structures are common in tidal flat setting and some subtidal environments where current flow or wave activity causes sand deposition, alternating with slack-water conditions that favour mud deposition ${ }^{32}$. These beddings may also form in marine and lacustrine delta-front environments, where fluctuations in sediment supply and current velocity are common; and possibly on shallow-marine shelves owing to storm-related transport of sand into deeper-water zones of mud deposition ${ }^{30,34}$. Hummocky crossstratification (Figure $4 d$ ) occurs in some manner under the action of waves and commonly appears in the ancient sediments deposited on the shoreface and shelf ${ }^{35}$. Hummocky cross-stratification seems to occur typically in fine sandstone to coarse siltstone that usually contains abundant mica and fine carbonaceous plant debris ${ }^{36}$. Moreover, hummocky cross-stratification originates by a combination of unidirectional and oscillatory flows related to storm activity ${ }^{35,36}$. The 'ripple cross-lamination' (Figure $4 e$ ) in the Kussak Formation is formed when deposition takes place rapidly during migration of current or wave ripples. A series of cross-laminae are produced by superimposing migrating ripples. These are formed when the ripples migrate and when rate of addition of sand was high and there was no net removal of sand from stoss$\operatorname{side}^{37,38}$. Synaeresis cracks (Figure $4 f$ ) are subaqueous shrinkage cracks that form in clayey sediments by loss of pore water because of reorganization of originally highly porous clays, either because of flocculation or change in volume of certain clay minerals due to salinity ${ }^{39}$. Marginal marine settings may be particularly favourable because changes in salinity may be due to clay ${ }^{33}$.

Sequence stratigraphic interpretation: The Cambrian, Khewra Sandstone and the Kussak Formation have been deposited during regression and transgression of the relative sea level that developed eight depositional subsequences, indicating a similar depositional environment. The strata of the Kussak Formation comprise of marine index mineral glauconite which is helpful in the interpretation of its sequence stratigraphy. This mineral forms at or near the sediments and water interfaces, and stays there for a long period. Thus, abundant occurrence of glauconite has traditionally been interpreted to reflect marine transgression, while lack of glauconite is associated with starvation, indicative of regression ${ }^{40}$. The link between glauconite and sedimentation rate has gained significant attention in sequence stratigraphy ${ }^{41}$. The depositional sequences in the Kussak Formation correspond to distinct phases of sea-level subsequences, and these phases govern sedimentation rates and percentage of glauconite in them. Glauconite mineral is present in KK-1 and KK-2 sequences, which indicates that deposition occurred during rise of relative sea level, i.e. transgressive system tract (TST) ${ }^{42}$. These deposits (TST) typically contain detrital glauconite, particularly near the base of the sequence. Moreover, mature authigenic glauconite generally increase upwards in TST deposits due to varying depositional environments, short-term sea-level dynamics and magnitude of sediment starvation. Additionally, fining upward subsequences indicate low-energy transgressive sequences. Glauconite is also present in KK-3, which occurs at the boundary between TST and highstand system tract (HST). KK-4 is a regressive sequence formed during the relative sea-level fall. These regressive deposits are followed by irregular surface of marine erosion or regressive marine surface (RMS). However, glauconite abundance and maturity generally decrease upward through this system tract. The KK-5 sequence is absent in the Nilawahan Gorge which appears to be eroded by the unconformity, thus having a pronounced effect in the central and western Salt Range and in the Nilawahan Gorge, where it cuts the Jutana dolomite in the eastern part of the section and the uppermost sequence in the western part of the section (Figure $7 c$ and $d$ ).

The Kussak Formation contains shallow shelf depositional sequence composed of fine- to medium-grained sandstone, siltstone, shale, greenish-grey glauconite and sandy dolomite. The lower part of the Kussak Formation associated with TST is characterized by low to moderate percentage of glauconite (Figure $7 a$ and $b$ ). The KK-3 forms the middle part of the Formation during HST. The sequences KK-4 and KK-5 indicate gradual rise in sealevel, dolomitic sandy contents and increase in glauconitic content thus are transregressive sequences. Moreover, these subsequences show asymmetrical internal cycles in sediment texture and reduction in glauconitic content. Overall deposition of the Kussak Formation is associated with transgressive period.

Sequence stratigraphic interpretation of the Kussak Formation: The sequence stratigraphic framework of the Kussak Formation has been established on the basis of well-log data and outcrop analysis. The Kussak Formation represents normal regressive to transgressive deposits from bottom to top (Figures 7-9). At the base of the Kussak Formation above the type-2 sequence boundary/ transgressive revinement surface, conglomerates are 
RESEARCH ARTICLES

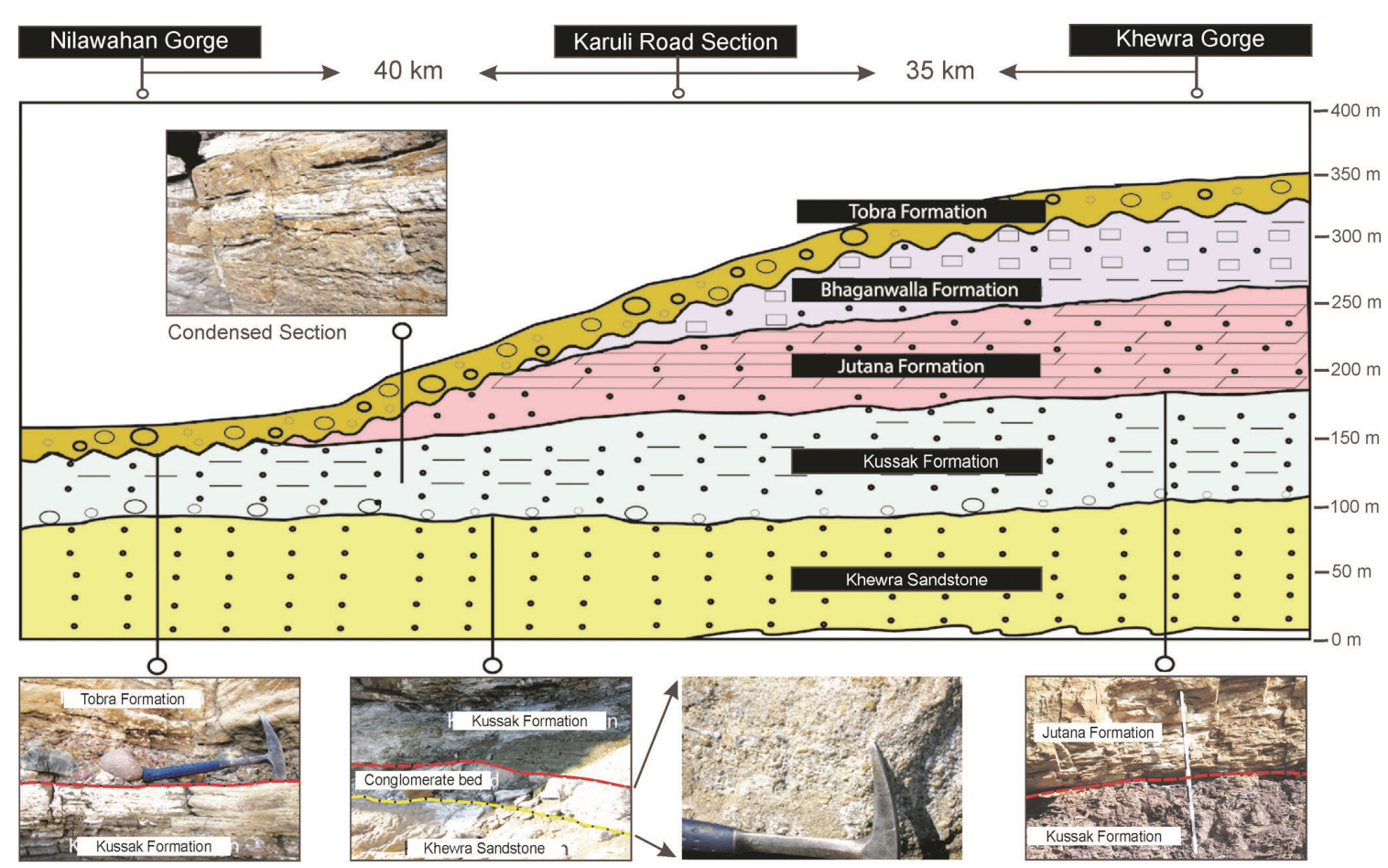

Figure 9. Stratigraphic strata at the Khewra Gorge, the Karuli Road Section and the Nilawahan Gorge of the Salt Range, Pakistan (modified after Hughes et al. ${ }^{3}$ ). (Inset) Photographs of the Khewra Gorge showing condensed section in the Kussak Formation, contact between the Kussak and Permian Tobra Formations, contact between the Khewra Sandstone and Kussak Formation, including a basal conglomerate bed, close-up of the conglomerate bed (hammer head for scale), and contact between the Jutana and Kussak Formations.

present which represent the transgressive lag deposits (Figure $7 a$ and $b$ ). GR $\log$ values of shale increase toward the top, which also confirms fining upward trends (Figure $8 d$ ). Furthermore, abnormal high values of GR show the condensed section at the top of this facies (Figures $7 a, b$ and $8 d$ ). After deposition of the condensed section, regression occurred in sequence KK-4 that deposited fine- to medium-grained sandstone and glauconitic shale. This is the only sequence that comprises of a coarsening upward or shoaling upward sequence. The GR $\log$ exhibits funnel-shaped motifs which also confirm the coarsening upward sequence, thus confirming that the deposition occurred during the regression phase (Figure $8 \mathrm{c}$ ). Above this, glauconitic sandstone interbedded with mud is also present. These deposits overall represent the fining upward sequence that indicates the transgression stage. Additionally, GR log shows bell-shaped motifs indicating overall fining upward trend (Figure $8 a$ and $b$ ). These deposits clearly depict TST (Figure $7 c$ and $d$ ) that make the upper part of the Kussak Formation. These sequences are bounded by TST that represents the smallscale variation of sea level during the Cambrian.

Consequently, depositional model of the Kussak Formation based on macroscopic, petrographic, sequence stratigraphic and log-based analysis was developed (Figure 10), which confirms renewed marine transgression of the formation that was probably a result of low detrital influx combined with continued eustatic sea-level rise. Zones of highly glauconitic arenite indicate that detrital input was at times nearly suspended. There is evidence of a possible disconformity at the base of the Kussak Formation. Overall, the Kussak Formation was deposited in deeper water with reduced detrital input and stronger water sedimentation. An offshore submarine bar also formed during deposition of the Kussak Formation. Clay and silt are lagoonal deposits and tidal flats shoreward of the submarine bar. Renewed progradation of the shoreline resulted in deposition of mixed sand/mud tidal flats. These were succeeded by the foreshore/shoreface and tidal channel deposits.

\section{Provenance of the Kussak Formation}

Relationships of the Cambrian Kussak Formation with rocks on the Indian Craton: The nature of the Neoproterozoic and Cambrian strata in both the Salt Range and Panjab-Ganganagar-Nagaur basin suggests a proximal and continental interior setting ${ }^{3}$. The core data show relatively shallower basin toward the south and bounded by a fault $\mathrm{t}^{43}$. The lowermost strata are sandstone of the Jodhpur Group containing putative Ediacaran fossils, which are overlain at the southern margin of the basin by carbonate of the Bilara Formation and, in the basin interior, by the Hanseran evaporite ${ }^{3}$. Moreover, geochemical data clarify their contemporaneous deposition ${ }^{44}$. These evaporites are up to $652 \mathrm{~m}$ thick in one borehole ${ }^{45}$, and they grade laterally southward into $300 \mathrm{~m}$ thick carbonate of the Bilara 


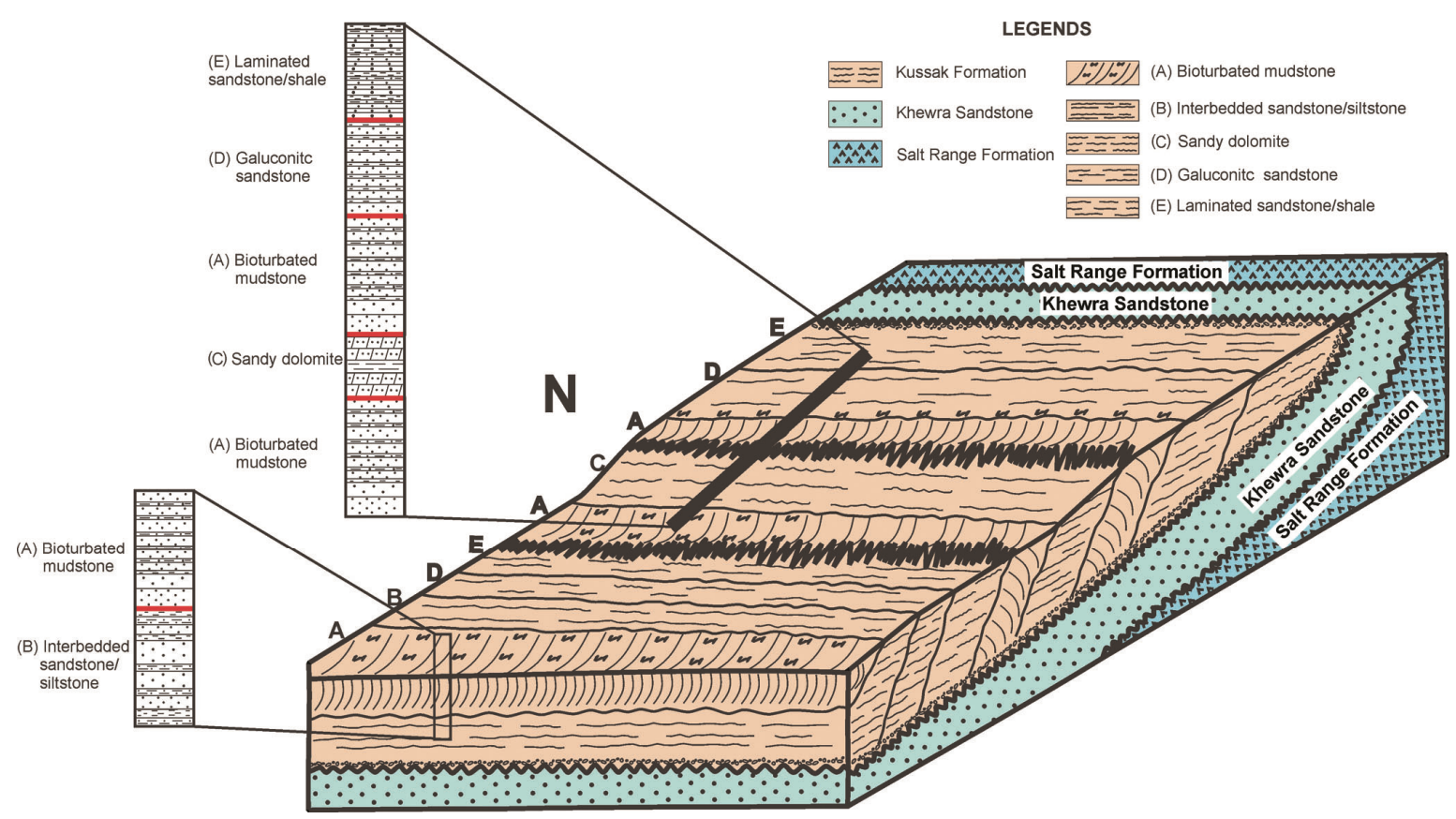

Figure 10. Depositional model of the Cambrian Kussak Formation, Salt Range, Pakistan.

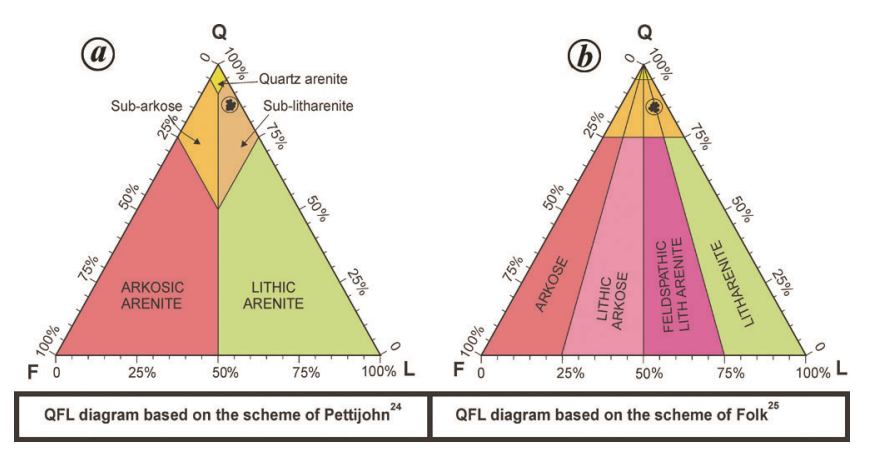

Figure $11 \boldsymbol{a}, \boldsymbol{b}$. Representation of characteristics of microfacies of the Cambrian Kussak Formation on the quartz, feldspar and lithic fragments diagram.

Group, and further southwards are less than $100 \mathrm{~m}$ in outcrop $^{46}$.

The overlying siliciclastic succession of the Nagaur Group (i.e. Nagaur Sandstone and Tunklian Formation) ranges from $75 \mathrm{~m}$ thick in outcrop to over $750 \mathrm{~m}$ thick in the subsurface Rajasthan basin ${ }^{45-47}$. The Nagaur Sandstone is the lower part of the Nagaur Group that comprises of cross-bedded red sandstone and thin mudstone beds, which locally has a basal, $5 \mathrm{~m}$ thick polymictic conglomeratic unit, the Khichan Conglomerate ${ }^{46}$. At depths within the Rajasthan basin, the Nagaur Sandstone contains evaporite horizons up to $100 \mathrm{~m}^{\text {thick }}{ }^{46}$. The overlying Tunklian Formation is locally coarse-grained ${ }^{48}$. The lithofacies of the Nagaur Sandstone is comparable with the Khewra Sandstone and Kussak Formation of the Salt Range. A lateral equivalent of the Tunklian Formation in core is the 'upper carbonate' unit, which is up to more than $500 \mathrm{~m}$ thick $^{3,47}$, and which may correlate with either the Jutana Formation or Khisor Formation, north of the Himalayan Frontal Thrust.

Petrographic interpretation: Thin-section studies of sandstone were carried out to determine the provenance of the Early Cambrian Kussak Formation. The petrographic studies depict that the major types of grains in sandstone are nonundulatory monocrystalline quartz, undulatory monocrystalline quartz, some polycrystalline quartz, orthoclase, plagioclase, microcline, few perthites, lithic fragments, abundant glauconite and accessory minerals such as mica and hematite. The QFL diagram of detrital grains of the Kussak Formation was constructed (Figure 11), which depicts $85-86 \%$ quartz, 3-4\% feldspar and $1 \%$ rock fragment, representing the abundance of quartz arenite in the sandstone samples.

Monocrystalline detrital quartz is medium- to coarsegrained and is most likely derived from weathering of granites $^{49}$, whereas fine-grained monocrystalline are most probably a product of breakage chipping of larger quartz grains derived from an igneous provenance. By contrast, polycrystalline elongated and stretched quartz grains are possibly derived from a metamorphic source ${ }^{50}$, such as granite gneiss or schist. In addition, the exceptionally rounded to well-rounded nature of some quartz grains is indicative of a recycled sedimentary source ${ }^{49}$.

Detrital K-feldspar grains are mainly derived from either acidic igneous rocks or from granite and gneisses, whereas plagioclase feldspar grains are mainly derived from low-grade mica schist ${ }^{51}$. The detrital feldspar grains therefore likely indicate both an igneous and a metamorphic source. Detrital micas were most likely derived from low-grade metamorphic rocks like quartzite, schist and 
gneisses, or from plutonic igneous rocks of granitic composition $^{52}$.

The above discussion confirms that the main detrital components of the Kussak Formation are monocrystalline quartz, feldspar, polycrystalline quartz, few lithic fragments and accessory minerals like mica and hematite. Monocrystalline quartz is about $95 \%$ of the total quartz showing nonundulatory to slightly undulatory extinction. Single quartz units contain inclusions and some grains are fractured. Their main source is plutonic rocks; mainly granitic rocks ${ }^{2}$. The main source of polycrystalline quartz which is about $5 \%$ of the total quartz is plutonic and lowgrade metamorphic rocks ${ }^{2}$. Dominant feldspar types are orthoclase and microcline, angular to sub-rounded, mainly derived from plutonic rocks such as granites and gneiss ${ }^{2}$. Mica flakes are average $<0.2 \mathrm{~mm}$ long and their source is mainly low-grade metamorphic rocks such as quartzite, schist and gneiss; and igneous rocks like granite ${ }^{2}$. Therefore, based on the above detrital components, the source of these grains is most probably: the Aravalli system, and the Malani Range.

(a) Aravalli system: The Precambrian Aravalli Supergroup is exposed in a range of hills in the region around Udaipur, Rajasthan, India, more than $600 \mathrm{~km}$ to the southeast of the Salt Range, and is composed of a complex suite of granitic, sedimentary and metamorphic rocks which themselves rest on an earlier banded gneiss complex. The provenance analysis presented herein demonstrates that rocks of the Aravalli Supergroup formed in uplifting, during which they were actively shedding detritus to the northwest.

(b) Malani range: The Malani Suite forms a series of volcanic porphyritic rhyolite lavas, intrusive granites and ash beds that cover an area of $51,000 \mathrm{~km}^{2}$ in the Barmer district, Rajasthan, India. It extends into the Sindh Province of Pakistan, which is more than $500 \mathrm{~km}$ to the south of the Salt Range. The grains of the Malani Range are also common within the early Cambrian sequence ${ }^{2}$. Therefore, the Malani Range is most probably another source area of the Kussak Formation that shed detritus northwards at that time.

\section{Conclusions}

The sedimentological and sequence stratigraphic characteristics of the Early Cambrian Kussak Formation were studied at the Khewra Gorge, the Karuli Road Section and the Nilawahan Gorge of Salt Range, Pakistan, where the Kussak Formation exhibits fining upward sequence and shows cyclic depositional trend. The intercalations of silt and claystone were present throughout the succession. At the top of the succession, medium-grained sandstone with shale intercalations resulted from renewed marine transgression. Moreover, this is the result of low detrital influx that continuously raises the eustatic sea-level. The zone of highly glauconitic arenite indicates that detrital input was at times nearly suspended, which was confirmed by disconformity at the base of the Kussak Formation. Overall, the Formation is deposited in deeper water with reduced detrital input and clearer water sedimentation. Clay and silt reveal lagoonal, whereas mixed sand/mud shows tidal flats environment. Moreover, sedimentary structures in the Kussak Formation confirm the tidal flats origin of the Formation. The petrographic studies represent abundance of glauconite that indicates marine continental shelfal environment. Consequently, lithofacies and petrographic analyses confirm the subtidal, intertidal to supratidal depositional environment of the Early Cambrian Kussak Formation. Additionally, sequence stratigraphy confirms that deposition of the Formation occurred during TST and HST. Petrographic studies demonstrate that the Kussak Formation shows quartz to feldspar, and very high grains to matrix ratios which confirm that sandstone of the formation is chemically and physically quite mature. In addition, quartz arenite of the Kussak Formation depicts the mixed provenance. However, relative abundance of quartz represents the Aravalli and Malani Ranges as the source area, which are about $550 \mathrm{~km}$ away from the present Salt Range.

1. Noetling, F., On the Cambrian formation of the Eastern Salt Range. Rec. Geol. Surv. India, 1894, 27(3), 71-86.

2. Ghazi, S. and Mountney, N. P., Petrography and provenance of the Early Permian Fluvial Warchha Sandstone, Salt Range, Pakistan. Sediment. Geol., 2011, 233(1-4), 88-110.

3. Hughes, N. C., Myrow, P. M., Ghazi, S., McKenzie, N. R., Stockli, D. F. and DiPietro, J. A., Cambrian geology of the Salt Range of Pakistan: linking the Himalayan margin to the Indian craton. Geol. Soc. Am. Bull., 2019, 131(7-8), 1095-1114.

4. Wynne, A. B., On the geology of the Salt Range in the Punjab. Mem. Geol. Surv. India, 1878, 14(17), 1-313.

5. Waagen, W., Salt-range fossils; fossils from the Ceratite formation; Pisces-Ammonoidea: Ibid. Mem. Palaeont. Indica, Ser. 13, 1895, 2, 324.

6. Fatmi, A. N., Lithostratigraphic units of Kohat-Potwar Province, Indus basin. Mem. Geol. Surv. Pak., 1973, 10, 1-80.

7. Bhargava, O. N., Early Palaeozoic palaeogeography, basin configuration, palaeoclimate and tectonics in the Indian plate. Geol. Soc. India Mem., 2011, 78, 69-99.

8. Shah, S. M. I., Stratigraphy of Pakistan, Geological Survey of Pakistan, 2009, pp. 245-273.

9. Middlemiss, C. S., Notes on the geology of the Salt Range of the Punjab, with a reconsidered theory of the origin and age of the Salt Marl. Rec. Geol. Surv. India, 1891, 24, 19-42.

10. Gee, E. R., Overview of the geology and structure of the Salt Range, with observations on related areas of northern Pakistan. Geol. Soc. Am. Spec. Publ., 1989, 232, 95-112.

11. Hughes, N. C., The Cambrian palaeontological record of the Indian subcontinent. Earth-Sci. Rev., 2016, 159, 428-461.

12. Jell, P. A. and Hughes, N. C., Himalayan Cambrian trilobites. Spec. Pap. Palaeontol., 1997, 58, 1-113.

13. Popov, L. E., Holmer, L. E., Hughes, N. C., Ghobadi Pour, M. and Myrow, P. M., Himalayan Cambrian brachiopods. Pap. Palaeontol., 2015, 1(4), 345-399.

14. Kruse, P. D. and Hughes, N. C., Himalayan Cambrian hyoliths. Pap. Palaeontol., 2016, 2(3), 323-341. 


\section{RESEARCH ARTICLES}

15. Valdiya, K. S., Proterozoic sedimentation and Pan-African geodynamic development in the Himalaya. Precambrian Res., 1995, 74, 35-55.

16. Searle, M. P., Structural evolution and sequence of thrusting in the high Himalaya, Tibetan-Tethys and Indus suture zones of Zanskar and Ladakh, Western Himalaya. J. Struct. Geol., 1986, 8, 923936.

17. Jaumé, S. C. and Lillie, R. J., Mechanics of the Salt Range-Potwar Plateau, Pakistan: a fold-and-thrust belt underlain by evaporates. Tectonics, 1988, 7(1), 57-71.

18. DiPietro, J. A. and Pogue, K. R., Tectonostratigraphic subdivisions of the Himalaya: a view from the west. Tectonics, 2004 23(5), 1-20.

19. Ghazi, S., Sharif, S., Hanif, T., Ahmad, S., Aziz, T. and Riaz, M., Micropaleontological analysis of the Early Eocene Sakesar Limestone, Central Salt Range, Pakistan. Pak. J. Sci., 2015, 67(2), 150 158 .

20. Davis, D. M. and Lillie, R. J., Changing mechanical response during continental collision: active examples from the foreland thrust belts of Pakistan. J. Struct. Geol., 1994, 16(1), 21-34.

21. Pascoe, E. H., The age of the Saline Series of the Punjab Salt Range. Proc. Natl. Acad. Sci. India, 1945, 14(6), 206-213.

22. Ahmad, N., Ahsan, N., Sameeni, S. J., Mirag, M. A. F. and Khan, B., Sedimentology of the Early-Middle Cambrian Jutana Formation of Khewra Gorge area, Eastern Salt Range, District Chakwal, Pakistan. Sci. Int., 2013, 25(3), 551-558.

23. Khan, S. and Shah, M. M., Multiphase dolomitization in the Jutana Formation (Cambrian), Salt Range (Pakistan): evidences from field observations, microscopic studies and isotopic analysis. Geol. Acta, 2019, 17(2), 1-18.

24. Pettijohn, F. J., Sedimentary Rocks (Vol. 3), Harper \& Row, New York, USA, 1975.

25. Folk, R. L., Petrology of Sedimentary Rocks, Hemphill, Texas, USA, 1974, p. 182.

26. Lindsay, J. F., Sequence stratigraphy and depositional controls in Late Proterozoic-Early Cambrain sediments of Amedeus Basin, Central Australia. Am. Assoc. Pet. Geol. Bull., 1987, 71, 13871403.

27. Reading, H. G. and Collinson, J. D., Facies and Stratigraphy (ed Readings, H. G.), Blackwell Science, Oxford, UK, 1996, pp. 154231.

28. Mossier, J. H., Sedimentary rocks of Dresbachian age (Late Cambrian), Hollandale Embayment, southeastern Minnesota. Minnesota Geol. Surv., 1992, 40, 1-71.

29. Reading, H. G. (ed.), Sedimentary Environments: Processes, Facies and Stratigraphy, John Wiley, United States, 2009, 3rd edn.

30. Reineck, H. E. and Singh, I. B., Depositional Sedimentary Environments: With Reference to Terrigenous Clastics, Springer, Science \& Business Media, Germany, 2012.

31. Bathurst, R. G. C., Boring algae, micrite envelopes, and lithification of molluscan biosparites. Geol. J., 1966, 5, 15-32.

32. Boggs Jr, S., Principles of Sedimentology and Stratigraphy, Pearson Education, 2014

33. Collinson, J. D., Alluvial sediments. In Sedimentary Environments (ed. Reading, H. G.), 1996, pp. 37-82.

34. Reineck, H. E. and Singh, I. B., Tidal flat. In Depositional Sedimentary Environments, Springer, Berlin, Germany, 1980.

35. Cheel, R. J. and Leckie, D. A., Hummocky cross-stratification. In Sedimentology Review 1, Blackwell, Oxford, UK, 1993, 2nd edn, pp. 103-122.
36. Duke, W. L., Hummocky cross-stratification, tropical hurricanes, and intense winter storms. Sedimentology, 1985, 32(2), 167-194.

37. Allen, G. P., Sedimentary processes and facies in the Gironde estuary: a recent model for macrotidal estuarine systems. A.A.P.G. Spec. Publ., 1991, 29-39.

38. Tucker, M. E., Sedimentary Petrology, Blackwell Scientific Publications, London, UK, 2001, p. 272.

39. Markhasin, B., Sedimentology and stratigraphy of the Lower Triassic Montney Formation, subsurface of northwestern Alberta. Master dissertation, University of Calgary, Canada, 1998.

40. Udgata, D., Glauconite as an indicator of sequence stratigraphic packages in a lower Paleocene passive-margin shelf succession, Central Alabama, Doctoral dissertation, Auburn University, United States of America, 2007.

41. Banerjee, S., Mondal, S., Chakraborty, P. P. and Meena, S. S., Distinctive compositional characteristics and evolutionary trend of Precambrian glaucony: example from Bhalukona Formation, Chhattisgarh basin, India. Precambrian Res., 2015, 271, 33-48.

42. Carter, R. M., Two models: global sea-level change and sequence stratigraphic architecture. Sediment. Geol., 1998, 122, 23-36.

43. Kumar, V. and Chandra, R., Geology and evolution of NagaurGanganagar basin with special reference to salt and potash mineralization. Geol. Surv. India, Spec. Publ., 2005, 62, 151.

44. Mazumdar, A. and Strauss, H., Sulfur and strontium isotopic compositions of carbonate and evaporite rocks from the late Neoproterozoic-early Cambrian Bilara Group (Nagaur-Ganganagar basin, India): constraints of intrabasinal correlation and global sulfur cycle. Precambrian Res., 2006, 149, 217-230.

45. DasGupta, S. P., Kumar, V. and Jairam, M. S., A framework of the Nagaur-Ganganagar evaporate basin, Rajasthan. Ind. Miner., 1988, 42(1), 57-64.

46. Pareek, H. S., Basin configuration and sedimentary stratigraphy of western Rajasthan. J. Geol. Soc. India, 1981, 22, 517-527.

47. Prasad, B., Asher, R. and Borgohai, B., Late Neoproterozoic (Ediacaran)-early Palaeozoic (Cambrian) acritarchs from the Marwar Supergroup, Bikaner-Nagaur basin, Rajasthan. J. Geol. Soc. India, 2010, 75, 415-431.

48. Pandey, D. K. and Bahadur, T., A review of the stratigraphy of Marwar Supergroup of west-central Rajasthan. J. Geol. Soc. India, 2009, 73, 747-758.

49. Pettijohn, F. J., Potter, P. E. and Siever, R., Sand and Sandstone, Springer Science \& Business Media, Germany, 2012.

50. Blatt, H., Original characteristics of clastic quartz grains. J. Sediment. Res., 1967, 37(2), 401-424.

51. Bhushan, S. K., Neoproterozoic magmatism of the Malani igneous suite, western Rajasthan, India. Geol. Surv. India, Spec. Publ., 2000, 55, 318-331

52. Khan, M. A., Lithological classification and environment of deposition of the Khussak Formation, Khewra Gorge, Salt Range. Geol. Bull. Univ. Peshawar, 1971, 6(1), 43-48.

ACKNOWLEDGEMENTS. We thank the Institute of Geology, University of the Punjab, Lahore, Pakistan for providing funds for the field work. We also thank the reviewers for valuable remarks and suggestions that helped improve the manuscript.

Received 14 September 2019; revised accepted 3 September 2020

doi: $10.18520 / \mathrm{cs} / \mathrm{v} 119 / \mathrm{i} 10 / 1671-1684$ 